\title{
Idiosyncratic Viral Loss Theory: Systemic Operational Losses in Banks
}

\author{
Sophia Beckett Velez ${ }^{+}$(i)
}

check for

updates

Citation: Velez, Sophia Beckett. 2021 Idiosyncratic Viral Loss Theory: Systemic Operational Losses in Banks. Journal of Risk and Financial Management 14: 82. https://doi.org/ 10.3390/jrfm14020082

Academic Editors: Shigeyuki Hamori and Stephen Satchell

Received: 17 January 2021

Accepted: 16 February 2021

Published: 18 February 2021

Publisher's Note: MDPI stays neutral with regard to jurisdictional claims in published maps and institutional affiliations.

Copyright: (c) 2021 by the author Licensee MDPI, Basel, Switzerland. This article is an open access article distributed under the terms and conditions of the Creative Commons Attribution (CC BY) license (https:/ / creativecommons.org/licenses/by/ $4.0 /)$.
College of Management and Technology, School of Management, Walden University, 100 Washington, Avenue South, Suite 900, Minneapolis, MN 55401, USA; sophia.velez@waldenu.edu

+ Sophia Beckett Velez Ph.D. has worked over 16 years as a Certified Public Accountant (CPA) with large banks providing consulting services. As a CPA, she worked for firms such as PriceWaterhoCoopers LLP (PwC), where she performed financial audits and attestation services for large banks.

Abstract: Basel III regulation intent is to increase the resiliency of banks through effective risk management practices that can reduce significant idiosyncratic operational losses. A systemic risk event that leads to significant losses in a bank holding company (BHC) can expose them to become insolvent and cause significant volatility and unpredictable negative impact on the United States economy. The viral spread of operational losses through global markets by interconnected multinational banks can be compared to viruses spread through interconnected countries and the significant losses incurred; this can be referred to as idiosyncratic viral loss theory. This idiosyncratic viral loss theory discusses systemic operational losses that are evident in human error, fraud, and legal expenses that are aligned to systemic operational risk. The occurrences of significant losses that are idiosyncratic in nature and that are linked to failed internal processes, people, systems, and external events are defined by the Basel Committee on Banking Supervision as operational risk losses; these losses' idiosyncratic nature makes them comparable to viruses. This study employs the Compliance and Ethics Group's (OCEG's) standard that integrates governance, risk management, internal control, assurance, and compliance (GRC capability model) into one functional goal to improve quality and principled performance through measurable tools that may enhance effectiveness and efficiency practices. This study concerns senior manager activities that can be effective towards meeting effective risk management practices posed by the Basel III regulation for BHCs, which may reduce the spread of significant losses in the banks. Through the use of a qualitative e-Delphi study, 10 banking finance experts were convened to build consensus on effective risk management practices. Data were collected from three electronic questionnaires submitted through Qualtrics. Data were analyzed using theoretical triangulation, coding, and thematic analysis. Four important considerations were identified that could bolster effective risk management practices: (a) a comprehensive enterprise-wide risk; (b) controlling fraud; (c) going beyond the minimum risk assessment requirements set forth by the banking regulators; $(\mathrm{d})$ independent risk identification and management. These considerations towards effective risk management practices may help reduce systemic operational losses viral spread in banks.

Keywords: idiosyncratic loss; viruses; COVID-19; systemic risk; operational risk; banks; SIFI; risk management

\section{Introduction and Background}

Idiosyncratic viral losses are a growing threat to the banking and global financial services industry that cannot be ignored. Significant financial institutions (SIFI) such as banks that sustain significant losses without adequate capital may become insolvent and pose a systemic risk to the US economy (Berger et al. 2018; Crawford 2017; Gong et al. 2018). Senior managers at JPMorgan Chase lost more than USD six billion in the "London Whale" scandal in 2012, jeopardized customers' deposits (Ertürk 2016), and paid a USD 100 million fraud settlement fee to the regulators (Patton 2014). Handorf (2017) discussed 
interconnected financial market loss examples where MF Global filed for bankruptcy in 2011 after becoming the largest US victim of the European debt crisis and lost more than USD 1.5 billion through overly aggressive trading strategies in the global markets. This interconnected financial market makes banks vulnerable to losses spreading from US markets to European markets; this lack of borders in interconnected financial markets is easily comparable to the spread and replication of RNA viruses on domestic and global fronts. RNA viruses multiply and mutate based on the environment and can have severe negative impacts (Oldstone 2020). A virus that causes a health emergency can have pandemic costs of USD 570 billion per year (Lee et al. 2020). Similarly, loss events may be viral, idiosyncratic, and systemic and have catastrophic effects on banks; these losses are typically hard to predict (Kaspereit et al. 2017). The unpredictable nature of these losses is a primary reason they are referred to as idiosyncratic and are often linked to operational risk. The Basel Committee on Banking Supervision defined operational risk as the risk of losses incurred due to failed internal processes, people and systems, and external events (BCBS 2006). Viewed from the perspective of operational risk, human error, fraud, and legal expenses are the seeds of idiosyncratic viral losses that are systemic in nature and thrive in a hotbed of a poorly maintained operational environment. Kaspereit et al. (2017) contends that operational loss events should be treated as idiosyncratic. The operational environment can be an incubator for systemic viral losses to breathe and exponentially spread based on the nature of the control environment.

Basel III was passed as a reaction to the 2008 recession in the US to remediate the capital adequacy issues faced by the banking sector due to the occurrence of significant losses in bank holding companies (BHCs) that may be operational losses in nature. Basel III required a larger proportion of bank capital to be of high quality and conduct an annual Comprehensive Capital Analysis and Review (CCAR) stress test (Wall 2017).

Despite the passage of Basel III capital regulation (Wilmarth 2011), BHCs have continued to sustain significant losses, increased operational risk exposure, and are unable to use the stress test to predict these idiosyncratic losses.

The main motivation for this study is to determine what the level of consensus is among banking finance experts across the United States on how to recognize effective risk management practice in BHCs. These practices towards risk management can assist senior managers to meet the Basel III requirements while minimizing systemic operational losses in banks' viral spread that may result in them becoming insolvent. The need for effective capital regulation practices has been documented as a necessary requirement to reduce agency theory risk exposure, evident in abusive high-frequency trading practices (Barr 2017). The problem is that BHCs lack practices that can be effective as risk management measures that can reduce viral idiosyncratic significant losses that affect the global banking sector. Baker and Filbeck (2015) mentioned that there is a need for a risk management framework that will enable a firm to cope with risk during extreme events.

To solve this problem, an e-Delphi study was employed to build consensus among 10 banking finance experts across the United States on how to identify effective risk management practices in banks that can reduce significant losses. The Delphi method explores an area of future thinking that goes beyond what is currently known or believed (Hsu and Sandford 2007). This technique gathers expert predictions under the guidance of a facilitator who controls these forecasts until group consensus is established (Ibiyemi et al. 2016). Three rounds of questionnaires were submitted to each panelist through an online platform: the first-round questionnaire was an open-ended approach to gather expert opinions on a certain issue; the second questionnaire asked the panel of experts to rank these statements, and third, the group reached a consensus (Cole et al. 2013; Donohoe et al. 2012). The consensus was set at $60 \%$, meaning six out of the ten participants vote on the identified risk management practices. The process allowed the grouping of statements that failed to satisfy consensus, shown in Section 4.2, and statements that satisfied consensus, shown in Section 4.3. The results were examined through the lens of the Compliance and Ethics Group's (OCEG) standards that incorporate compliance as a measure to improve 
quality and "principled performance", which may enhance effectiveness and efficiency practices (Bezzina et al. 2014). The advantage of the Delphi study is clear, as banking experts reach consensus on important considerations, discussed in Section 4, that should accompany risk management measures, including emphasis placed on a risk management framework.

This article is structured as follows: First, the literature on BHC idiosyncratic viral losses and lack of effective risk management practices is reviewed. Then, the research methodology, including the sampling strategy, is described. Next, the findings of the impact of important considerations that should accompany risk management measures are presented. Finally, the article concludes with a list of key findings and recommendations.

\section{Literature Review and Conceptual Framework}

The conceptual framework for this e-Delphi study was framed by OCEG's standard that integrates governance, risk management, internal control, assurance, and compliance (GRC capability model) into one functional goal to improve quality and principled performance through measurable tools that may enhance effectiveness and efficiency practices (Bezzina et al. 2014). In several studies, Grant Thornton International argued that the integration of governance, risk management, and compliance can improve effectiveness and efficiency performance (Bezzina et al. 2014). Multinational operational losses that are idiosyncratic, unpredictable, and spread across and impact the global markets can be referred to in idiosyncratic viral loss theory. Idiosyncratic viral loss theory discusses systemic operational loss spread and behavior that are evident in human error, fraud, and legal expenses that are aligned to systemic operational risk. The occurrences of significant losses that are idiosyncratic in nature and that are linked to failed internal processes, people, systems, and external events are defined by the Basel Committee on Banking Supervision as operational risk losses; these losses' idiosyncratic nature makes them comparable to viruses. This study employs OCEG's standard that integrates governance, risk management, internal control, assurance, and compliance (GRC capability model) into one functional goal to improve quality and principled performance through measurable tools that may enhance effectiveness and efficiency practices. Limited research exists on effective risk management measures to address operational risk and significant losses in BHCs (Berger et al. 2018; Dowd and Hutchinson 2016). In recent years, several factors (housing boom, aggressive lending activity, financial innovation, and increased access to money) increased bank risk and contributed to them experiencing significant losses (Egly et al. 2016).

Idiosyncratic viral loss theory derives its label from its character-its likeness in behavior to that of viruses, unpredictable formation, environment, spread rate, and global impacts; this behavior can be referred to in viral loss theory. When significant operational losses that are idiosyncratic in nature occur in the banking sector in the United States, the impact and presence replicate in the global banking and financial sector. Similarly, viruses penetrate the living environment, evolve strategies to express their genes, replicate, and assemble their component parts into multiple copies or offspring (Oldstone 2020). A recent exhibition of this type of virus is the novel coronavirus disease 2019 (COVID-19), an infectious disease, idiosyncratic in nature, which is caused by a new virus first detected in Wuhan, China, December 2019; the global spread rate of this virus resulted in a global health emergency, declared by the World Health Organization (WHO) on 11 March 2020 to be a pandemic (Tariku and Hajure 2020). Viruses are toxic and can kill their host cells; RNA viruses evolve one million times faster than DNA viruses (Oldstone 2020).

The unpredictable nature of viruses makes them idiosyncratic; an important undertaking using models can indicate that Rt $>1$ signals exponentially increasing incidence of the virus (Parag and Donnelly 2020). However, we are forewarned that inferring R from epidemic data to make experimental choices and estimates can be deceptive or unreliable (Parag and Donnelly 2020). Idiosyncratic operational loss events in BHCs are hard to predict and not anticipatory by the stock market investors (Kaspereit et al. 2017). The task of predicting significant losses that can spawn a recession is a struggle many banks and 
the Federal Reserve Bank (Fed) face alike. The Fed requires banks to use scenario analysis models to predict significant operational losses; the reliance on historical data made them questionable in their capability to predict actual market risk and losses (Velez et al. 2020).

\subsection{Impact of Idiosyncratic Viral Losses in Large Multinational Banks}

The impact of idiosyncratic viral losses in large multinational banks without adequate capital has exposed them to insolvency and poses a systemic risk to the US economy (Berger et al. 2018; Crawford 2017; Gong et al. 2018). Losses in multinational banks spread to the global economy because of their interconnectedness. Handorf (2017) discussed interconnected financial market loss examples where MF Global filed for bankruptcy in 2011 after becoming the largest US victim of the European debt crisis and lost more than USD 1.5 billion through overly aggressive trading strategies; JPMorgan suffered a USD six billion idiosyncratic loss from the currency default swap market and faced another USD one billion in fines from the London Whale scandal, Similarly, the behavior of viruses and the recent coronavirus has displayed how interconnectedness facilitates global spread and impact rapidly; the COVID-19 health crisis demonstrates how our global system is organized around global cities and their international connections-epidemics can become global crises (Pierantoni et al. 2020). The level of interconnectedness of the financial markets on a global level was highlighted in the 2007 financial crisis. Some of these interconnected firms were multinational firms that operated globally and were deemed as "too big to fail" (TBTF); they received special treatment from their respective central banks and regulators. The subprime collapse in 2007 spawned the financial crisis and triggered the bankruptcy of the major investment banks Bear Stearns and Lehman Brothers in 2008; Central Banks and governments around the world, in response to the crash of the financial markets, launched bailouts and monetary policies (Deos et al. 2015). Velez (2020) mentioned the United States bailouts to TBTF institutions during the 2007-2009 US recessions; Fannie Mae and Freddie Mac were placed into conservatorship, and AIG and IndyMac, along with 700 banks, received USD 245 billion in Fed bailout funds.

Troubled Asset Relief Program (TARP) was the bailout fund that was authorized by Congress in October 2008; originally authorized for USD 700 billion, USD 313 billion was disbursed to the financial sector, and they paid back USD 321 billion (Velez 2020). AIG was given USD 182 billion at various points; the government received that amount in full, plus an additional profit of USD 23 billion (Fahey 2016). Similarly, Germany and UK central banks bailed out their TBTF financial institutions. Government bailouts provided to private financial institutions increased monetary base as well as the debt burden of states and are visible in the financial statements of central banks; the financial statement of the European Central Bank grew by 241\% (Hale 2016). Biljanovska (2016) argues that TBTF banks in the 2007 financial crisis found themselves in a phenomenon with the regulatory authorities; regulators suspended ordinary insolvency laws and rules to prevent their failures to prevent the severe repercussions they would have on the financial market and the US economy. The insolvency laws were deemed inadequate against these systemic risk intuitions and they were bailed out by their respective central banks and regulators; the taxpayers assumed the bailout cost of these systemic risk banks (Biljanovska 2016). Velez et al. (2020) contends that having governance, risk management, internal control, assurance and compliance, supervision, and regulation measures with more robust laws for winding up or resolving too-big-to-fail financial institutions' crises can be a more effective way to deal with TBTF institutions. The failure of stress test measures to predict market risk and losses is seen as a significant danger to the financial sector's stability (Velez et al. 2020). The idiosyncratic losses that banking models failed to predict in relation to mortgage back securities negatively affected the US markets and spread to the global banking industry.

\subsection{Idiosyncratic Loss Classification: Human Error, Fraud, and Legal Expenses}

Idiosyncratic losses are usually classified in groups defined by their nature of occurrence as human error, fraud, and legal expenses, and they are viral and systemic to 
domestic and global economies. The environment in which these types of events occurred can foster their exponential growth or containment/slow down their growth rate. Whenever organizations have failed internal processes, people and systems, and external events, this breeds significant operational losses (BCBS 2006); the state of the control environment can contribute to the growth of or reduction in operational losses. Fadun and Oy (2020) asserted that the lack of internal control and the unmanaged operational risk in the control environment of large banks resulted in significant losses of USD 7.2 billion at Société Générale in 2008. Similarly, environments contribute to virus outbreaks that cause significant loss of lives and financial losses. As of $2018,55 \%$ of the world's population lived in urban areas, and this is projected to increase to $68 \%$ by 2050 ; many outbreaks of infectious diseases have originated in urban settings, such as COVID-19 in Wuhan, China, and rapidly propagated because of densely populated environments (Lee et al. 2020). The Zika virus outbreak in America and Severe acute respiratory syndrome (SARS) in 2003 started in urban cities; many of these locations are interconnected, important hubs of travel and trade that impact the economy negatively if not contained, giving rise to significant losses and loss of lives (Lee et al. 2020). Likewise, significant financial institutions (SIFIs) and banks are interconnected environments that can foster the spread of exponential losses that are operational in nature. Interconnected structures can cause instability, and large losses can be transmitted to other banks, thereby exposing the entire financial system to systemic failures (Allen et al. 2016). On the other hand, interconnected financial networks have been used to transfer losses and dividends among banks to facilitate stability and absorb any negative idiosyncratic shocks (Allen et al. 2016). The enhancement of SIFIs' regulation may not prevent systemic risk, but the measuring of systemic risk can lead to the design of effective financial stability policies (Allen et al. 2016). The maintenance of debt that would convert to capital in response to specific market indicators of financial distress could help prevent firms from failing (Allen et al. 2016). The containment of losses has been a global effort through the implementation of internal control activities and government oversight. Likewise, in the containment of viruses, governments have looked to risk management practices in the form of policies-for example, China's use of effective policies in controlling the epidemic and suggestion to other countries to implement strong policies in alignment with their national conditions to control COVID-19 (Li et al. 2020). Environments that fail to control domestic fraud events spread to a global level, exposing the financial markets to significant losses.

\subsection{Fraud and Legal Expense: Systemic Operational Losses}

There is significant viral growth of operational losses in the financial sector linked to market manipulations that are fraudulent in nature. Thefts, mortgage fraud, and predatory lending are principal-agent problems that spawned significant operational losses in large banks during the most recent financial crisis (Lui 2011). There are internal and external frauds in the international banking sector that are operational risk events identified by the Data Operational Riskdata eXchange Association (ORX) (Martínez-Sánchez et al. 2016). Operational losses stemming from risk events caused by external frauds include (a) fraud and theft losses incurred due to a fraudulent act, misappropriation of property, or circumvention of the law by a third party without the cooperation of the bank employee; (b) security system event losses relates to unauthorized access to electronic data files (Martínez-Sánchez et al. 2016). On the other, internal fraud operational risk events include (a) fraud and theft losses incurred due to fraudulent acts, misappropriations of goods, and circumvention of government regulation and company policy by internal banking staff; (b) unauthorized activities that cause losses tied to unreported intentional and unauthorized operations and intentionally unregistered positions; (c) security system losses stemming from unauthorized access to electronic data files for personal profit with the assistance of an internal employee's access (Martínez-Sánchez et al. 2016). The Federal government and various foreign governments have implemented various regulatory laws to discourage and contain the growing spread of internal fraud in financial institutions, namely the banking 
sector. The increase in financial regulators' power through Basel III and the Dodd-Frank Bill law positions them to increase their global crackdown on fraud and insider trading; market regulators believed that insider trading is harmful to the capital markets (Montagano 2012). Fraud in the capital markets can manifest in the form of an affected financial institution and its competitors' use of negative and material information in an attempt to alter market participants' perception; these firms were fined by US and European authorities (Kaspereit et al. 2017). Several banks received fines from the government/regulators, one being Barclays Bank fined a GBP 59.5 million penalty for manipulating the London Interbank Offered Rate ("LIBOR") and the euro Interbank Offered Rate ("EURIBOR") in June 2012; Swiss global financial services company (UBS) (GBP 160 million) in 2012, Royal Bank of Scotland (GBP 87.5 million), Rabobank (GBP 105 million) in 2013, Lloyds Bank (GBP 105 million) in 2014, and Deutsche Bank (GBP 226 million) in 2015 (Kaspereit et al. 2017).

Legal expenses that are unpredictable and non-recurring in nature are often not planned for. They are usually tied to human behavior, and the unpredictable nature of these expenses makes them idiosyncratic and often systemic. Whenever there is a failure in internal processes and people practices, the expenses from these events are defined as operational risks (BCBS 2006). Legal expenses that cause losses are tied to operational risk; these operation risk events are tied to losses due to fraudulent acts, inappropriate appropriations of goods, or evasion of regulation policy by internal staff (Martínez-Sánchez et al. 2016). Strebel et al. (2016) mentioned the JPMorgan Chase and Co. 2012 nine-page document which laid out the company's malpractice and ongoing legal proceeding in the origination and servicing of mortgages, and the company accepted a total settlement of USD 5.3 billion in 2012; an additional settlement was reached of USD 1.9 billion relating to the allegations of irregularities in its mortgage foreclosure activities. Further, JPMorgan Chase and Co. agreed to a penalty of USD 13 billion in 2013 relating to allegations of misrepresentation to the public and to investors of the sale of several mortgage-backed securities (Strebel et al. 2016).

Many of these banks suffer reputational damages that manifest in operational losses from government fines and government exposure for these fraudulent activities; this has negatively impacted the stock prices of these companies. Kaspereit et al. (2017) discussed 403 loss data from Algorithmics, Inc. (operational loss database and loss events), which reflects a statistically significant negative impact on stock price in reaction to operational loss announcements for US banks and insurers; the market value loss significantly exceeds the operational loss amount due to the negative impact on company reputation.

\subsection{Human Error: Systemic Operational Losses}

Human errors are a prevalent form of idiosyncratic losses that are an operational risk faced by many SIFIs and banks. Banks are required to perform stress tests and use scenarios to predict their losses as required by the Dodd-Frank Bill 2010, Section 165, which was passed in response to the 2008 financial crisis (Velez et al. 2020). These measures in the Dodd-Frank Bill 2010, Section 165, are required to be a part of banks' internal control and compliance practices. It has been challenging for banks to proactively manage their operational risk in a business environment with idiosyncratic volatility (MartínezSánchez et al. 2016). SIFIs need advanced tools, models, techniques, and methodologies that combine internal data with external industry data in their self-assessment and scenario modeling that can project significant financial losses (Martínez-Sánchez et al. 2016). Banks receive significant fines and penalties from the Fed for lack of compliance with Dodd-Frank Bill 2010 measures. The regulators require banks to manage their operational risk; Fadun and Oy (2020) mentioned the lack of internal control practices by institutions such as Aviva and Wells Fargo, whose cases in 2016 resulted in them paying GBP 8.2 million and USD 187.5 million in penalties, respectively. The Fed requires large banks to use financial models to predict their potential operational losses; these stress test measures were found to be limited in predicting market risk and losses and are being viewed as a possible danger to the financial sector (Velez et al. 2020). Bellof and When (2018) mentioned human errors as 
a challenge that banks encountered during the implementation or use of these models that contributed to operational risk that was not detected in the subprime and financial crises.

Similarly, models such as the renewal or branching process model have been used to predict the spread of Ebola and Zika virus disease outbreaks and to investigate the COVID19 pandemic (Parag and Donnelly 2020). The estimated COVID-19 cases in Hubei Province were predicted to peak at 51,222 with policy intervention, and without intervention, to reach 157,721, which is vital to epidemic control (Li et al. 2020). Internal control measures embedded in the policies were quarantine of infected individuals to block transmission, closing cities, extending holidays, restricting population mobility, banning crowd gathering, and taking temperatures, which identifies infected individuals (Li et al. 2020). Epidemic control and preparedness are less costly, estimated approximately at USD 4.5 billion per year compared to estimated health emergency pandemic costs of USD 570 billion per year (Lee et al. 2020). Correspondingly, financial markets are exposed to billions of dollars in losses due to the lack of an appropriate operational risk management environment (Martínez-Sánchez et al. 2016). Fadun and Oy (2020) mentioned approximately USD 175.5 million and USD 22 million in losses incurred by Bank of America and Citigroup, respectively, in 2012 and USD one billion and EUR 252 million by Rabobank and FondiariaSIA, respectively, in 2013. Velez et al. (2020) mentioned the Fed-implemented policies that include compliance and internal control measures that will minimize risk by controlling losses and the maintenance of a minimum net capital ratio percentage of eight percent. The decrease in losses stemming from human errors and fraud is attainable through the implementation of practices aligned to heightened ethical awareness that can reduce fraudulent behaviors and better bank managers' business choices.

\section{Research Methodology}

The Delphi technique is a consensus-building process that uses rounds of questionnaires to gather opinions from members of a structured expert panel to inform change (Izaryk and Skarakis-Doyle 2017). Data are collected in a naturalistic manner through surveys that ask "how", "why", and "what" questions that are open-ended in nature (Gaus 2017). The potential of the e-Delphi technique is in its consensus-building process that has three rounds of questionnaires to gather opinions from banking finance experts across the United States. To perform this e-Delphi study, 10 finance experts who have been employed for a minimum of 10 years in banking, possess an MBA in Finance, and are currently employed as a consultant to a large bank in the US were identified to form a panel of experts. Participants were recruited via social media (LinkedIn groups) and an initial survey consisting of five questions was submitted with subsequent follow-up rounds. Data were collected from three electronic questionnaires submitted through Qualtrics. The study data and theoretical triangulation practice increase confidence in the research data, reveal unique findings, integrate theories, and allow to understand the problem (Thurmond 2001). Data comparison was used to gather multiple sources of survey responses collected at different times and compare them. The study was conducted with multiple lenses and questions that lend support to the findings (Thurmond 2001).

\subsection{Sample}

The purpose of the study and the open-ended nature of the research questions supported the Delphi design. Email invitations were sent to potential participants and a link to an expert screening e-survey was administered using Qualtrics (Cole et al. 2013). This e-Delphi method combined expert opinions to arrive at an informed group consensus on a complex problem (Davidson 2013; Guzys et al. 2015). Purposive sampling was employed to recruit 10 experts from across the United States to form a panel with experience in the underlining study constructs. Participants were recruited via social media (LinkedIn groups) and an initial survey consisting of five questions was submitted with subsequent follow-up rounds. The individuals were elected as part of a panel of expert participants because of their background and knowledge on the subject. The inclusion criteria for 
participation in this e-Delphi study as a panelist were as follows: (1) adult over the age of 18, (2) employed for a minimum of 10 years in the banking industry, (3) possession of an MBA in Finance, and (4) currently employed as a consultant to a large bank in the United States. These criteria were aligned with guidelines for expert judgment in model-based economic evaluations (Iglesias et al. 2016).

\subsection{Data Collection}

The e-Delphi design was used to collect critical data electronically through the process of surveys that ask "how", "why", and "what" questions that are open-ended in nature (Gaus 2017). The three data-collection instruments consisted of electronic questionnaires. The first-round questionnaire used an open-ended approach to gather expert opinions on a certain issue; the second questionnaire asked the panel of experts to rank these statements, and finally, the group reached consensus (Cole et al. 2013; Donohoe et al. 2012). In the first round, the questionnaire required experts to list and briefly describe at least five responses to questions (see Hirschhorn 2019; Okoli and Pawlowski 2004). In the second round, the panelists were provided the questionnaire developed based on the answers from Round 1 (a generated aggregated list of statements based on Round 1 questions) (see Okoli and Pawlowski 2004). The experts were asked to shortlist the responses on the listed inventories produced based on the relevance and ability to provide insights on the most critical aspects of the research questions (Hirschhorn 2019). In Round 3, the panelists received a questionnaire generated with the Round 2 responses. The experts were asked to rate each statement from the second-round questionnaire against two separate (desirability and feasibility) 5-point Likert scales.

\subsection{Data Analysis}

The experts' responses to open-ended questions were qualitatively analyzed and coded, major themes were identified, and the information identified contributed to the study findings (Hirschhorn 2019). The data derived from the questions were coded and then the themes were linked to classification grounded in the conceptual framework and the literature. The key phrases from the Round 1 responses that answered each research question were highlighted and pattern coded to collect similar coded statements (Saldaña 2016). The application of content analysis identified themes, patterns, indexing, and categories, with non-recurring evidence associated with individual cases (Saldaña 2016). In Round 2, an inventory list was sent to the panelists (see Hirschhorn 2019). The panelists were asked to vote on the inventory list and a shortlist was generated based on majority votes. The panelists voted for each statement on the second-round questionnaire on two separate (desirability and feasibility) 5-point Likert scales. Desirability measures ranged from (1) highly undesirable to (5) highly desirable, and feasibility ranged from (1) definitely infeasible to (5) definitely feasible. In Round 3, the experts were asked in this rating process to consider the elements shortlisted in Round 2 and to rate each statement on the secondround questionnaire on two separate (desirability and feasibility) 5-point Likert scales. The data analysis revealed a consensus on four effective risk management practices that can reduce significant losses in banks.

\section{Results}

4.1. Research Question: Describe Risk Management Practices Senior Bank Managers Implement towards Capital Regulation that Can Be Effective in Reducing Losses in Bank Holding Companies

The panelists' recommendations for risk management practices in the first-round questionnaire generated 20 statements that can be effective in reducing losses in BHCs. These 20 statements were provided to the panelists in Round 2 for the panelists to rate each statement on two separate (desirability and feasibility) 5-point Likert scales. Desirability measures ranged from (1) highly undesirable to (5) highly desirable, and feasibility ranged from (1) definitely infeasible to (5) definitely feasible. The results of the voting in Round 2 generated 16 statements that were used to construct the Round 3 questionnaire. The 
panelists were asked to rate, in this final round, the 16 statements based on 5-point Likert scales. Four statements received 6 out of 10 votes and met the consensus threshold of $60 \%$. Table 1 contains the number of statements in each round and the overall study findings. Table 2 contains data corresponding to the voting results from each round of the study.

Table 1. Overall Study Findings.

\begin{tabular}{cccccc}
\hline Category & $\begin{array}{c}\text { Round 1 Generated } \\
\text { Statements }\end{array}$ & $\begin{array}{c}\text { Round 2 } \\
\text { Statements }\end{array}$ & $\begin{array}{c}\text { Round 3 } \\
\text { Statements }\end{array}$ & $\begin{array}{c}\text { Consensus } \\
\text { Statements }\end{array}$ & $\begin{array}{c}\text { Portion of Statements } \\
\text { Representing Consensus }\end{array}$ \\
\hline $\begin{array}{c}\text { Risk } \\
\text { Management }\end{array}$ & 20 & 20 & 16 & 4 & $12 \%$ \\
\hline
\end{tabular}

Table 2. Statements Failing to Meet Consensus Threshold in Round 2 and 3.

\begin{tabular}{|c|c|c|}
\hline Statement & Rating (Desirability) & Rating (Feasibility) \\
\hline $\begin{array}{l}\text { Risk management practice towards capital regulation that can be effective in reducing losses } \\
\text { includes communication within the entire organization. }\end{array}$ & 2 & 2 \\
\hline $\begin{array}{l}\text { Risk management practice towards capital regulation that can be effective in reducing losses } \\
\text { includes evaluating all small and capital budget projects from a risk perspective. }\end{array}$ & 1 & 3 \\
\hline $\begin{array}{l}\text { Risk management practice towards capital regulation that can be effective in reducing losses } \\
\text { includes an independent data infrastructure. }\end{array}$ & 1 & 5 \\
\hline $\begin{array}{l}\text { Risk management practice towards capital regulation that can be effective in reducing losses } \\
\text { includes an independent controls process in place. }\end{array}$ & 2 & 5 \\
\hline $\begin{array}{l}\text { Risk management practice towards capital regulation that can be effective in reducing losses } \\
\text { includes employing lines of defense when approaching risk within the organization. }\end{array}$ & 4 & 5 \\
\hline $\begin{array}{l}\text { Risk management practice towards capital regulation that can be effective in reducing losses } \\
\text { includes market overall exposure limitations. }\end{array}$ & 5 & 4 \\
\hline $\begin{array}{l}\text { Risk management practice towards capital regulation that can be effective in reducing losses } \\
\text { includes best practices in financial risk management (The Committee of Sponsoring }\end{array}$ & 4 & 4 \\
\hline Organizations of the Treadway Commission (COSO), Sarbanes Oxley (SOX), BASEL III, etc.). & & \\
\hline $\begin{array}{l}\text { Risk management practice towards capital regulation that can be effective in reducing losses } \\
\text { includes hiring and maintaining Subject matter experts (SMEs) to create and maintain risk } \\
\text { management policies and procedures. }\end{array}$ & 4 & 5 \\
\hline $\begin{array}{l}\text { Risk management practice towards capital regulation that can be effective in reducing losses } \\
\text { includes common access to critical data with common language. }\end{array}$ & 5 & 4 \\
\hline $\begin{array}{l}\text { Risk management practice towards capital regulation that can be effective in reducing losses } \\
\text { includes adoption of risk management tools and governance. }\end{array}$ & 4 & 4 \\
\hline $\begin{array}{l}\text { Risk management practice towards capital regulation that can be effective in reducing losses } \\
\text { includes prioritization of recurrent risk assessment. }\end{array}$ & 4 & 3 \\
\hline $\begin{array}{l}\text { Risk management practice towards capital regulation that can be effective in reducing losses } \\
\text { includes culture of accountability. }\end{array}$ & 5 & 3 \\
\hline $\begin{array}{l}\text { Risk management practice towards capital regulation that can be effective in reducing losses } \\
\text { includes adherence to regulations such as Reg CC. }\end{array}$ & 4 & 5 \\
\hline $\begin{array}{c}\text { Risk management practice towards capital regulation that can be effective in reducing losses } \\
\text { includes having frequent training of employers to ensure adherence to banking industry } \\
\text { rules and regulations. }\end{array}$ & 5 & 4 \\
\hline $\begin{array}{l}\text { Risk management practice towards capital regulation that can be effective in reducing losses } \\
\text { includes ensuring change requests are a requirement for any internal updates or change and } \\
\text { a risk assessment evaluation completed. }\end{array}$ & 5 & 6 \\
\hline $\begin{array}{l}\text { Risk management practice towards capital regulation that can be effective in reducing losses } \\
\text { includes implementation of an effective risk control self-assessment program. }\end{array}$ & 5 & 5 \\
\hline
\end{tabular}

\subsection{Statements That Failed to Satisfy Consensus Threshold}

Risk management statements that did not satisfy the consensus level of at least six of the 10 votes in Round 3 were identified as non-consensus statements. As indicated in Table 2, 16 statements failed to meet consensus threshold in Round 3.

\subsection{Statements That Satisfied the Consensus Threshold}

Risk management statements that had at least six of the 10 votes, a $60 \%$ consensus, in Round 3 were identified as consensus statements. As indicated in Table 3, four statements had at least six of the 10 votes, reaching a $60 \%$ consensus in Round 3. 
Table 3. Statements that Satisfied Consensus Threshold in Round 3.

\begin{tabular}{ccc} 
Statement & Rating (Desirability) & Rating (Feasibility) \\
\hline $\begin{array}{c}\text { Risk management practice towards capital regulation that can be effective in } \\
\text { reducing losses includes a comprehensive enterprise-wide risk management } \\
\text { framework that includes daily activities. }\end{array}$ & 6 & 4 \\
$\begin{array}{c}\text { Risk management practice towards capital regulation that can be effective in } \\
\text { reducing losses includes controlling fraud. }\end{array}$ & 6 & 3 \\
$\begin{array}{c}\text { Risk management practice towards capital regulation that can be effective in } \\
\text { reducing losses includes going beyond the minimum risk assessment } \\
\text { requirements set forth by the banking regulators. }\end{array}$ & 6 \\
$\begin{array}{c}\text { Risk management practice towards capital regulation that can be effective in } \\
\text { reducing losses includes independent risk identification and management. }\end{array}$ & 6 \\
\hline
\end{tabular}

A comprehensive enterprise-wide risk management framework supports the assertions of Baker and Filbeck (2015) that a risk management framework that encompass three major components of risk analysis: modeling, measuring, and managing, which will enable a firm to cope with risk during both normal times and extreme events. Risk mitigation should incorporate model risk measures that identify economically dangerous uncertainties and their risk factors; a quantitative assessment and risk measurement approach to risk embedded in financial decision-making, portfolio and investment planning, and the respective management activities (Baker and Filbeck 2015). Lui (2011) mentioned that mortgage fraud, predatory lending, managerial slack and risk shifting, and the issuance of bad loans due to a weak risk management environment are aligned to significant losses in banks. The findings extend Lui's (2011) work by drawing attention to (a) risk management efforts aimed at controlling fraud and (b) going above and beyond the minimum risk assessment requirements set forth by banking regulators. Giordana and Schumacher (2017) stated that Basel III could decrease the probabilities of default for banks and maybe would have reduced default risk during a crisis episode if it had previously implemented, which highlights the importance of Basel III and risk identification.

\section{Conclusions}

The intent of risk management practices emphasized in Basel III regulation is to increase the resiliency of banks and reduce significant idiosyncratic operational losses. Banks' significant losses can be compared to idiosyncratic viral losses. The combination of human error, fraud, and legal expenses are aligned to systemic operational risk. Idiosyncratic losses are a continuous global threat to the sustainability of the global financial markets. The spread rate of the risk posed to domestic and global markets by these losses is comparable to that of viruses. Idiosyncratic viral loss theory derives its label from its character, its likeness in behavior to that of viruses in terms of unpredictable formation, environment, spread rate, and global impacts. Despite the passage of the Basel III capital regulation, BHCs have continued to sustain significant losses and increased operational risk exposure, and their inability to predict their idiosyncratic losses has motivated this study to determine the level of consensus among banking finance experts across the United States on how to recognize effective risk management practices. As a result, our conclusion may add knowledge on important considerations that should accompany risk management measures and extends concepts in OCEG standards that implement risk management as a measure to improve quality and performance.

The review of statements that are identified as non-consensus and consensus highlights the areas for banks to consider when addressing the central problem of effective risk management measures in BHCs. The consensus statements identified risk management activities that can be effective in BHCs, while non-consensus ones are deemed unfavorable by the panelists in terms of effectiveness towards losses and Basel III. Sixteen statements did not satisfy the consensus threshold, while four statements met the consensus threshold that identifies considerations that should accompany risk management measures to reduce 
significant losses and achieve effectiveness in BHCs. Consensus statements that could be effective practice refer to enterprise-wide risk management frameworks that includes daily activities, controlling fraud, going beyond the minimum risk assessment requirements set forth by the banking regulators, and independent risk identification and management. The consensus statements may reduce operational losses that are idiosyncratic in nature, occurring in the banking sector in the United States. Practitioners and the Federal Reserve Bank (Fed) are recommended to use these statements to construct policies, procedures, and training programs that may lead to reduction in risky management behaviors. These recommendations can help facilitate a respectable risk culture that may inform managerial decisions, thereby reducing financial risk taking that leads to losses.

Scholars may conduct further studies to compare and contrast the results of this E-Delphi study in many ways. This study did not confine the experts in banking to a specific region in the United States; scholars may desire to conduct further studies on this central research topic using different delimitations. One boundary included the decision to focus the overall research question on effective risk management practices. The decision to develop a conceptual framework based on OCEG standards that integrates governance, risk management, internal control, assurance, and compliance (GRC capability model) and the use of the Delphi method are also delimitations. Future scholars may want to use different panelist criteria from those used in this study. The criteria for this study confined panelists to individuals: (1) adult over the age of 18; (2) employed for a minimum of 10 years in the banking industry; (3) possession of an MBA in Finance; and (4) currently employed as a consultant to a large bank in the United States. Scholars may modify panel eligibility criteria to include industry-specific experience and prior professional and academic publications. There is a potential difference in the functionality of banks in different states and geographic regions within the United States, and Delphi studies on this topic localized to a specific region may present a viable option for future research.

Funding: This research received no external funding.

Conflicts of Interest: The author declares no conflict of interest.

\section{References}

Allen, Franklin, Itay Goldstein, Julapa Jagtiani, and William W. Lang. 2016. Enhancing prudential standards in financial regulations. Journal of Financial Services Research 49: 133-49. [CrossRef]

Baker, H. Kent, and Greg Filbeck. 2015. Risk management: A panel discussion. Journal of Applied Finance 25: 46-57.

Barr, Michael S. 2017. Financial reform: Making the system safer and fairer. RSF: The Russell Sage Foundation. Journal of the Social Sciences 3: 2-18.

BCBS. 2006. Basel II: International Convergence of Capital Measurement and Capital Standards: A Revised FrameworkComprehensive Version. Available online: www.bis.org/publ/bcbs128.htm (accessed on 12 June 2019).

Bellof, Tilo, and Carsten S. When. 2018. On the treatment of model risk in the internal capital dequacy assessment process. Journal of Applied Finance and Banking 8: 1-15. Available online: http:/ / www.scienpress.com/journal_focus.asp?Main_Id=56 (accessed on 12 June 2019).

Berger, Allen N., Filippo Curti, Atanas Mihov, and John Sedunov. 2018. Operational risk is more systemic than you think: Evidence from US bank holding companies. SSRN. [CrossRef]

Bezzina, Frank, Simon Grima, and Josephine Mamo. 2014. Risk management practices adopted by financial firms in Malta. Managerial Finance 40: 587-612. [CrossRef]

Biljanovska, Biljana. 2016. Aligning market discipline and financial stability: A more gradual shift from contingent convertible capital to bail-in measures. European Business Organization Law Review 17: 105-35. [CrossRef]

Cole, Zachary Douglas, Holly M. Donohoe, and Michael L. Stellefson. 2013. Internet-based Delphi research: Case based discussion. Environmental Management 51: 511-23. [CrossRef]

Crawford, J. 2017. Lesson unlearned?: Regulatory reform and financial stability in the Trump Administration. In Columbia Law Review Online. forthcoming; UC Hastings Research Paper No. 242. Available online: https:/ / columbialawreview.org/ (accessed on 12 June 2019).

Davidson, Phillip L. 2013. The Delphi technique in doctoral research: Considerations and rationale. Review of Higher Education and Self-Learning 6: 53-65. Available online: www.intellectbase.org/journals (accessed on 12 June 2019).

Deos, Simone, Olívia Bullio, Ana Rosa Ribeiro de Mendonça, and Rosa Ribeiro. 2015. Banking-system transformations after the crisis and their impacts on regulation. The Journal of European Economic History 44: 77-111. Available online: https://ezp. 
waldenulibrary.org/login?url=https:/ / search-proquest-com.ezp.waldenulibrary.org/docview / 1784859343 ?accountid=14872 (accessed on 12 June 2019).

Donohoe, Holly, Michael Stellefson, and Bethany Tennant. 2012. Advantages and limitations of the e- Delphi technique: Implications for health education researchers. American Journal of Health Education 43: 38-46. [CrossRef]

Dowd, Kevin, and Martin Hutchinson. 2016. Learning the right lessons from the financial crisis. Cato Journal 36: 393-413. Available online: https: / / www.cato.org/ (accessed on 12 June 2019).

Egly, Peter V., Diego Escobari, and David W. Johnk. 2016. The impact of government intervention on the stabilization of domestic financial markets and on U.S. banks' asset composition. Journal of Economics and Finance 40: 683-713. [CrossRef]

Ertürk, Ismail. 2016. Financialization, bank business models and the limits of post-crisis bank regulation. Journal of Banking Regulation 17: 60-72. [CrossRef]

Fadun, Olajide Solomon, and Diekolola Oy. 2020. Impacts of operational risk management on financial performance: A case of commercial banks in Nigeria. International Journal of Finance and Banking Studies 9: 22-35. [CrossRef]

Fahey, Caitlin. 2016. Are We Ready for the Next Financial Crisis? Fordham Journal of Corporate and Financial Law 21: 232-94. Available online: https: / /ir.lawnet.fordham.edu/jcfl/ (accessed on 12 June 2019).

Giordana, Gastón Andrés, and Ingmar Schumacher. 2017. An empirical study on the impact of basel III standards on banks' default risk: The case of luxembourg. Journal of Risk and Financial Management 10: 8. [CrossRef]

Gaus, Nurdiana. 2017. Selecting research approaches and research designs: A reflective essay. Qualitative Research Journal 17: 99-112. [CrossRef]

Gong, Di, Harry Huizinga, and Luc Laeven. 2018. Nonconsolidated affiliates, bank capitalization, and risk taking. Journal of Banking and Finance 97: 109-29. [CrossRef]

Guzys, Diana, Virginia Dickson-Swift, Amanda Kenny, and Guinever Threlkeld. 2015. Gadamerian philosophical hermeneutics as a useful methodological framework for the Delphi technique. International Journal of Qualitative Studies on Health and Well-being 10: 26291. [CrossRef]

Hale, Balseven. 2016. The political economy of financial regulation policies following the global crisis. International Journal of Economics and Financial Issues 6. Available online: https:/ / ezp.waldenulibrary.org/login?url=https://search-proquest-com.ezp. waldenulibrary.org/docview/1787062139?accountid=14872 (accessed on 12 June 2019).

Handorf, William C. 2017. Regulatory ratios, CDS spreads, and credit ratings in a favorable economic environment. Journal of Banking Regulation 18: 268-85. [CrossRef]

Hirschhorn, Fabio. 2019. Reflections on the application of the Delphi method: Lessons from a case in public transport research. International Journal of Social Research Methodology 22: 309-22. [CrossRef]

Hsu, Chia-Chien, and Brian A. Sandford. 2007. The Delphi technique: Making sense of consensus. Practical Assessment, Research and Evaluation 12: 1-8. Available online: https:/ / www.pareonline.net/ (accessed on 12 June 2019).

Ibiyemi, Abayomi O., Mohd Adnan Yasmin, and Nasir Daud Md. 2016. The validity of the classical delphi applications for assessing the industrial sustainability-correction factor: An example study. Foresight: The Journal of Futures Studies, Strategic Thinking and Policy 18: 603-24. [CrossRef]

Iglesias, Cynthia P., Alexander Thompson, Wolf H. Rogowski, and Katherine Payne. 2016. Reporting guidelines for the use of expert judgement in model-based economic evaluations. PharmacoEconomics 34: 1161-72. [CrossRef]

Izaryk, Kristen, and Elizabeth Skarakis-Doyle. 2017. Using the delphi technique to explore complex concepts in speech-language pathology: An illustrative example from Children's social communication. American Journal of Speech-Language Pathology 26: 1225-35. [CrossRef]

Kaspereit, Thomas, Kerstin Lopatta, Suren Pakhchanyan, and Jörg Prokop. 2017. Systemic operational risk: Spillover effects of large operational losses in the european banking industry. The Journal of Risk Finance 18: 252-67. [CrossRef]

Lee, Vernon J., Marc Ho, Chen Wen Kai, Ximena Aguilera, David Heymann, and Annelies Wilder-Smith. 2020. Epidemic preparedness in urban settings: New challenges and opportunities. The Lancet Infectious Diseases 20: 527-29. [CrossRef]

Li, Bao-Zhu, Nv-Wei Cao, Hao-Yue Zhou, Xiu-Jie Chu, and Dong-Qing Ye. 2020. Strong policies control the spread of COVID-19 in china. Journal of Medical Virology. [CrossRef]

Lui, A. 2011. Multiple principal-agent problems in securitisation. The Poznan University of Economics Review 11: 47-72. Available online: http:/ / www.ebr.edu.pl/ (accessed on 12 June 2019).

Martínez-Sánchez, José Francisco, María Teresa V. Martínez-Palacios, and Francisco Venegas-Martínez. 2016. An analysis on operational risk in international banking: A bayesian approach (2007-2011)/Un análisis del riesgo operacional en la banca internacional: Un enfoque bayesiano (2007-2011). Estudios Gerenciales 32: 208-20. [CrossRef]

Montagano, Christopher P. 2012. The global crackdown on insider trading: A silver lining to the "great recession". Indiana Journal of Global Legal Studies 19: 575-98. Available online: http:/ / www.repository.law.indiana.edu/ijgls/vol19/iss2/10 (accessed on 12 June 2019). [CrossRef]

Okoli, Chitu, and Suzanne D. Pawlowski. 2004. The Delphi method as a research tool: An example, design considerations and applications. Information and Management 42: 15-29. [CrossRef]

Oldstone, M. B. 2020. Viruses, Plagues, and History: Past, Present, and Future. Oxford: Oxford University Press.

Parag, Kris V., and Christl A. Donnelly. 2020. Using information theory to optimise epidemic models for real-time prediction and estimation. PLoS Computational Biology 16. [CrossRef] 
Patton, Spencer P. 2014. Archangel problems: The SEC and corporate liability. Texas Law Review 92: 1717-56. Available online: https: / / texaslawreview.org/ (accessed on 12 June 2019).

Pierantoni, Ilenia, Mariano Pierantozzi, and Massimo Sargolini. 2020. COVID 19-A qualitative review for the reorganization of human living environments. Applied Sciences 10: 5576. [CrossRef]

Saldaña, Johnny. 2016. The Coding Manual for Qualitative Researchers, 3rd ed. Thousand Oaks: Sage Publications.

Strebel, P., M. Cording, and J. Shan. 2016. Competitive profits and the annual report: Measuring the sustainable business. The Journal of Business Strategy 37: 42-49. [CrossRef]

Tariku, Mandaras, and Mohammedamin Hajure. 2020. Available evidence and ongoing hypothesis on corona virus (COVID-19) and psychosis: Is corona virus and psychosis related? A narrative review. Psychology Research and Behavior Management 13: 701-4. [CrossRef]

Thurmond, Veronica A. 2001. The point of triangulation. Journal of Nursing Scholarship 33: 253-58. [CrossRef]

Velez, Sophia. 2020. Banking and Effective Capital Regulation in Practice: A Leadership Perspective. London: Routledge.

Velez, Sophia, Michael Neubert, and Daphne Halkias. 2020. Banking Finance Experts Consensus on Compliance in US Bank Holding Companies: An e-Delphi Study. Journal of Risk and Financial Management 13: 28. [CrossRef]

Wall, Larry D. 2017. Recent changes in US regulation of large foreign banking organizations. Journal of Financial Regulation and Compliance 25: 318-32. [CrossRef]

Wilmarth, Arthur E., Jr. 2011. The dodd-frank act's expansion of state authority to protect consumers of financial services. Journal of Corporation Law 36: 893-954. 